\title{
Holambra: turismo, patrimônio e perdas
}

\author{
Holambra (SP, Brazil): tourism, heritage and losses
}

\author{
João Luiz van Ham Mello, Solano de Souza Braga
}

\section{RESUMO}

O artigo apresenta a pesquisa realizada durante a monografia do curso de bacharelado em Turismo da Universidade Federal de Minas Gerais. O estudo de caso se acerca ao contexto urbano de Holambra, município do interior de São Paulo, situada a $130 \mathrm{~km}$ da cidade de São Paulo, possui atualmente cerca de treze mil habitantes e uma expressiva contribuição econômica e tecnológica no setor de flores e plantas ornamentais. $\mathrm{Na}$ área urbana da sede municipal as políticas urbanísticas foram determinantes para a construção e dinamização da paisagem urbana local e no desenvolvimento do turismo. Tais transformações no espaço e na paisagem foram responsáveis, segundo a hipótese em que o estudo de baseou, por consequências sócio espaciais que, na atualidade, configuram um novo momento de expansão e dinâmica urbana. Embora a cidade se destaque economicamente por sua qualidade de vida e tranquilidade, tem sua formação urbana muito recente. Foi emancipada de fazenda a município em 1991 e, desde então, foram implantadas políticas urbanísticas municipais que apoiaram o desenvolvimento urbano no que diz respeito, principalmente, ao paisagismo público e a caracterização de um cenário de lazer. O turismo, recente fenômeno sócio econômico que vem se desenvolvendo localmente, tem como seu principal objeto de atração a cultura holandesa em seus mais variados ramos de apreciação. As políticas voltadas ao turismo estão baseadas na cenarização e composição de espaços públicos de lazer.

PALAVRAS-CHAVE: Turismo; Patrimônio; Política. 


\section{ABSTRACT}

The article presents a research carried out during a monograph work in the bachelor course of Tourism of the Federal University of Minas Gerais. The case study is about the urban context of Holambra, a municipality in the interior of the state of São Paulo (Brazil), located $130 \mathrm{~km}$ from the city of São Paulo, that has about thirteen thousand inhabitants and an expressive economic and technological contribution in the flowers and ornamental plants sector. In the urban area of the municipal seat the urban policies were determinants for the construction and dynamization of the local urban landscape and on the development of tourism. Such transformations in space and landscape were responsible, according to the hypothesis that the study was based, due to socio-spatial consequences that currently constitute a new moment of expansion and urban dynamics. Although the city stands out economically for its quality of life and tranquility, it has a very recent urban formation. The municipality was emancipated from a farm in 1991 and, since then, municipal urban policies have been implemented and supported the urban development mainly concerning to public landscaping and the characterization of a leisure scenario. Tourism, a recent socio-economic phenomenon that has been developing locally, has as its main object of attraction the Dutch culture in its most varied branches of appreciation. Policies focused on tourism are based on the "scenario setting" and composition of public leisure spaces.

KEYWORDS: Tourism; Heritage; Policy.

\section{Introdução}

Este artigo tem sua origem em um trabalho de monografia sobre a dialética entre o turismo e a paisagem no contexto urbano da cidade de Holambra, no interior paulista. Neste estudo, identificou-se que a paisagem urbana, usufruída pela atividade turística na atualidade, teve seu precedente em políticas urbanísticas que influenciaram sobremaneira sua construção. Desta forma, criou-se neste município, de aproximadamente treze mil habitantes, um cenário de lazer voltado para a espetacularização da cultura holandesa, raiz cultural desta localidade.

A construção da paisagem turística é um processo que pode ser entendido a partir de duas perspectivas. De um lado, estão as intervenções urbanísticas pelo poder público e privado e por meio da arquitetura; do outro, os meios de comunicação que veiculam as imagens e descrevem os lugares e incentivam o imaginário social (SILVA, 2004).

Neste sentido, Bessa (2011) afirma que os "projetos turísticos de paisagem" podem ser entendidos a partir da ação estatal, dos discursos dos marcos regulatórios "criados para oficializar os projetos de intervenção. Leis, decretos, portarias, discursos podem revelar as intenções e ações do Estado em determinado projeto de intervenção" (BESSA, 2011, p.75). Parte-se do princípio que as paisagens turísticas são construídas socialmente e tem 
como intuito a caracterização dos lugares orientada para compreender interesses do poder público e da sociedade; como marco de uma identidade própria ao território e como produto do turismo.

Este processo, que vem se consolidando ao longo das duas últimas décadas, fez com que Holambra se tornasse nacionalmente conhecida pelo "pedacinho da Holanda no Brasil", ou a "Cidade das Flores". A colonização holandesa que aconteceu em 1948, foi o acontecimento responsável por esta dedicação à cultura holandesa que se observa hoje na Estância Turística ${ }^{1}$ de Holambra. A partir de sua emancipação de fazenda a município em 1991, criaram-se as devidas legislações municipais que deram o embasamento legal como forma de município brasileiro.

Diante destas transformações na ex-colônia de imigrantes holandeses, as políticas urbanísticas e o próprio processo de urbanização fizeram com que a fazenda se adequasse aos poucos, com muitos investimentos, à realidade brasileira. A dinâmica econômica desde a época da emancipação era baseada na produção e comercialização de flores e plantas ornamentais. Até a atualidade esta realidade se confirma diante da expressiva participação que Holambra apresenta no mercado de flores e plantas no Brasil. É o principal polo produtor e comerciante.

As políticas urbanísticas que deram forma legal às ações das instancias públicas municipais e ordenaram o território enquanto município, deram na época uma atenção especial ao turismo, um potencial de desenvolvimento econômico e social. Vislumbrou-se que a ex-colônia holandesa não poderia deixar que o progresso econômico e social esquecesse suas raízes de origem europeia. Para isso, com o intuito de desenvolver o turismo e criar uma "identidade" para Holambra, uma ementa municipal incentivou a construção de fachadas "típicas" holandesas nas construções prediais de caráter comercial e residencial, garantindo aos que fizessem tais modificações ornamentais, um abono de até $50 \%$ no valor do I.P.T.U. municipal.

Esta lei, em vigor desde 1994, fez com que a cidade ganhasse cada vez mais um aspecto paisagístico europeu, ou propriamente dito, holandês. O turismo que busca propiciar aos visitantes lugares com características pitorescas ao habitual e evidenciar culturas distintas do olhar comum²; achou seu lugar nesta construção de um cenário típico. Holambra como Estância Turística do Estado de São Paulo, desde 1998, não somente recebeu este título, como é receptora das benesses fiscais do Estado de São Paulo para o desenvolvimento do turismo.

Holambra tornou-se um destino turístico de expressão no que diz respeito à cultura holandesa e ao mercado de flores e plantas. A Expoflora, festa das flores, está em sua 34ํㅜ edição neste ano e conta com um público anual, que visita a cidade no mês de setembro, de 300.000 visitantes. Outros eventos que fazem menção à eventos comemorados também na Holanda, completam o calendário oficial da cidade. A cultura holandesa também se expressa na gastronomia local, nos artesanatos e souvenirs, nos atrativos turísticos, e na paisagem urbana. 
Não é à toa que o interesse fiscal provindo da atividade turística local enche os olhos de empresários, comerciantes e poder público. A paisagem que remete ao "típico" holandês também agrada aos turistas que, sem senso crítico, passam suas tardes buscando os símbolos da cultura prometida pelos catálogos de turismo e blogs na internet. A invenção da fachada holandesa representa o renascimento holandês dos séculos $\mathrm{XV}$ e XVI, presente nas cidades de Amsterdã, Utrecht e Haarlem, por exemplo.

A colônia de Holambra, com forma de governo cooperativista, faliu ainda na década de 1950, mas as tradições e costumes trazidos pelos holandeses, assim como as construções desta época edificadas pela Cooperativa Holambra, destinadas à armazenagem dos produtos da fazenda, assim como o comércio, a "igreja velha", a "antiga Escola São Paulo" e a "paineira velha" simplesmente, hoje, se perderam. A história de Holambra se vê resumida a alguns registros em um museu.

Desta forma, percebe-se que a história da colônia de Holambra, está se perdendo em meio a um cenário voltado ao "típico" holandês que se vê como patrimônio na Holanda atualmente nas grandes e médias cidades. $O$ turismo de características pós-modernas ${ }^{3}$, líquido ${ }^{4}$ e espetacular ${ }^{5}$ está $^{-}$ priorizando uma cultura do não-lugar ${ }^{6}$ em que basta ser belo para existir. Este artigo é uma tentativa de trazer à tona estas questões que permeiam o patrimônio, o turismo e as perdas que este processo ultimo tem ocasionado no interior paulista.

\section{Espaço, paisagem e turismo}

Estão apresentados nesta seção os conceitos teóricos dos termos "espaço", "paisagem" e "turismo" pois são elementos básicos de referência neste estudo. A bibliografia apresentada baseou-se em autores de vasto conhecimento nas áreas de pesquisa. O "espaço" é conceituado inicialmente para chegar-se a ideia de "paisagem", pois ambos são termos correspondentes. O conceito de "turismo" apresentado tem como objetivo adaptar-se ao conteúdo deste estudo, o que não significa que seja um termo com apenas uma leitura. Por se tratar de um conceito que envolve diversas áreas do conhecimento, restringiu-se ao objetivo proposto. O objeto geral deste arcabouço teórico é compreender o conceito de "paisagem turística".

\section{A dialética do espaço e da paisagem}

São variados os significados adotados para ambos os termos espaço e paisagem - sendo que distintas áreas de estudo e atuação se apropriam de um sentido, o qual Ihes parecer mais conveniente. Para este estudo, propõe-se apresentar os conceitos do espaço e da paisagem sob a conveniência da Nova Geografia escrita por autores como M. Santos (19262001) e H. Isnard (1904-1983).

A teoria proposta por Milton Santos para a compreensão do espaço é de grande relevância na literatura da Nova Geografia brasileira e internacional. Santos, ao definir o espaço, propõe o deslocamento de um 
conceito de sociedade que, anteriormente era definido por autores marxistas como Parsons e Smelser (1956), Jakubowsky (1975) e Bettelheim (1970) como simplesmente um sistema ou uma estrutura, mas sem considerar o espaço. Santos, por sua vez, apresenta o conceito de sociedade como sistema de ações que transforma o espaço SANTOS (2004).

O espaço como elemento geográfico e social pode ser entendido a partir dos diversos elementos que o compõem. Para Santos (1982), o espaço é entendido como o conjunto, a soma dos resultados da intervenção humana sobre a terra. Seria entendido como o resultado da síntese entre 0 trabalho morto (formas geográficas) e o trabalho vivo (o contexto social) (SANTOS, 1988). Neste ponto, considera-se que existem dois elementos que juntos formam e transformam o espaço: sistemas de ações e sistemas de objetos (SANTOS, 2008) "O espaço é resultado da ação sobre o próprio espaço, intermediado pelos objetos, naturais e artificiais" (SANTOS, 1988, p.71).

É fundamental na análise do espaço proposto por Santos, considerar o fenômeno tempo como fator evolutivo da transformação espacial. A sociedade, ou o sistema de ações está em constante mudança e, portanto, modifica o espaço. A forma (geográfica) "é alterada, renovada, suprimida para dar lugar a uma outra forma que atenda às necessidades novas da estrutura social' (SANTOS, 1982, p.38). H. Isnard (1982) reforça a teoria de Santos quando afirma que "não há sociedade sem espaço que lhe seja próprio, no interior do qual as gerações se sucedem numa continuidade tal, que uma identidade se realiza entre um povo e seu território".

Embora concorde com Santos no que diz respeito a indissociação entre sociedade e espaço, Isnard (1982) oferece uma posição contrária sobre a evolução em consonância de ambos. Ele afirma que "a sociedade cria-se, criando seu espaço: os dois formam, em conjunto, um todo indissociável que sofrem a mesma evolução" (p. 85). Diante disso, sobre os objetos (trabalho morto/ formas espaciais), Santos (2004) afirma que eles "são resistentes à mudança social e uma das razões disso está em que eles são também ou antes de tudo matéria" (p. 187).

Os processos espaciais são elementos físicos duráveis que detém de uma autonomia de permanência e, portanto, não são modificados ao mesmo instante que os processos sociais, mas tendem a sofrer alterações mais lentamente diante das necessidades destes processos (SANTOS, 1982; 2004). Diferentemente do espaço, mas em complementaridade a ele, a paisagem apresenta conceitos que formam com o espaço, um par dialético. A paisagem é senão, "a materialização de um instante da sociedade" (SANTOS, 1988, p.72).

A "paisagem" vista como uma espécie de patrimônio hegemônico da Geografia passou, a partir da centralização do estudo disciplinar que enfocou o "espaço' e o "território", a ser englobada por outros campos disciplinares, resultando em uma diversidade de conceituações teóricas e, portanto, incertezas. A "Nova Geografia" trata a paisagem de modo a considerar os diversos campos que tratam a temática. Os conceitos plurais tendem a extinguir o caráter paternalista, rural e tradicional da antiga geografia (DOMINGUES, 2001). Atualmente, a teoria da paisagem é 
amplamente discutida por estudiosos da Arquitetura e do Urbanismo, da Geografia, do Turismo e da Antropologia que, embora apresentem diferentes perspectivas, estes concordam quando apresentam a paisagem como elemento indissociável do espaço.

De acordo com Leite (1994), "a paisagem é resultado do equilíbrio entre múltiplas forças e processos temporais e espaciais" (p. 7). Significa dizer que, assim como o espaço, esta é "reflexo da visão social do sistema produtivo" (p.7) e é constantemente transformada segundo as técnicas, necessidades e interesses da sociedade (LEITE, 1994). Yágizi (2001), nessa mesma corrente interpretativa, afirmar que a paisagem "resulta do casamento do que uma sociedade herda e se apropria, com aquilo que suas necessidades praticam" (p.34).

Já Fusalba (2009, apud LEMOS, 2009) recorre a Antrop (1997) e discorre sobre a paisagem como um dos aspectos mais afetados pelos processos de mudança territorial quando afirma que no passado, as transformações no território eram mais lentas e facilmente absorvidas pelas pessoas, de maneira que os novos elementos se inseriam gradualmente no quadro psicológico das mesmas.

Sobre isso, segundo Auguste Comte e Maurice Halbwachs (1990 apud YÁZIGI, 2001), "o equilíbrio mental depende, em primeiro lugar, da estabilidade dos objetos materiais de nossa vida, que proporcionam uma imagem de permanência. Eles trazem nossa marca e a dos outros. O grupo transforma seu espaço à sua imagem e a ele se adapta" (p.36). A atualidade é caracterizada por uma instabilidade social marcada nos diversos âmbitos da vida, na qual as esferas política, econômica, cultural e social sofrem rápidas transformações. A adaptação dos grupos sociais se tornam mais complexas e, também, seus sentimentos de permanência e estabilidade.

Os europeus mostraram grande preocupação com os efeitos das mudanças territoriais no continente e criaram a partir do Conselho da Europa (2000) o Conselho Europeu da Paisagem (2000). Para este órgão, paisagem "désigne une partie de territoire telle que perçue par les populations, dont le caractère résulte de l'action de facteurs naturels et/ou humains et de leurs interrelations" (CONSEIL DE L'EUROPE, 2012, p. 13). O mesmo conselho sublinha a importância dos valores espirituais da paisagem para a sociedade: "le paysage en tant que composante essentielle du cadre de vie des populations, expression de la diversité de leur patrimoine commun culturel et naturel, et fondement de leur identité" (CONSEIL DE L'EUROPE [2], 2012, p. 6).

Para Yázigi (2001) "a paisagem teria atributos expressivamente simbólicos" (p.35) uma vez que ela "também faz parte da identidade do lugar" (p.37). Neste sentido, afirma que as identidades "não são dadas pela história mais antiga, mas por aquela sedimentada como processo de construção e suas relações de força" (p.17). A personalidade do lugar se dá a partir de um conjunto de elementos identitários como a história, a arquitetura, o urbanismo, os tipos humanos e suas relações com o meio, a pertença, as lendas, os sons, as formas linguísticas e "todos os diferenciais 
do próprio meio ambiente (relevo, hidrografia, fauna, flora, clima, etc.)" (YÁZIGI, 2001, p.45).

É certo dizer que o "instante da sociedade" como afirmou Santos, ou seja, a paisagem, é única a cada local. A construção da paisagem depende do resultado proveniente das diversas forças que atuam sobre ela em um determinado momento histórico, mas sua percepção e contemplação diz respeito a individualidade de cada ser humano por meio da visão.

Essa visão de Santos pode ser complementada pelo que afirma Fusalba (2009, apud LEMOS, 2009) sobre os dois tipos de realidades da paisagem: a realidade material de elementos tangíveis tanto naturais como antrópicos e uma realidade que procede a percepção humana subjetiva: "una percepción que da lugar a la imagen del paisaje que cada indivíduo construye en función de sus experiencias vitales ambientales, de los lazos afectivos que estabelece com los lugares y su carga de significados tanto de tipo individual como coletivo" (FULSABA, 2009 apud LEMOS 2009, p.141).

A percepção do meio por cada indivíduo torna a paisagem um objeto único de contemplação. O modo de contemplação é diverso pois, "depende do local de residência, idade, sexo, categoria social' (LEDRUT, 1973 apud YÁZIGI, 2001, p.47), "valores, sentimentos, estoque cultural, fantasias e imaginação” (MORANDI; GIL, 2001, p.19).

A contemplação da paisagem segundo Gomes (1999 apud SALGUEIRO, 2001) é um processo que ocorre em duas etapas: a observação "objetiva" "pois o conceito de paisagem é essencialmente visual" (p.41) e a necessidade de explicação do conjunto, pois há "dimensões ocultas" que dizem respeito à cultura, à organização política e econômica que não são objetivas.

A fim de dar prosseguimento a proposta deste estudo, faz-se necessário o entendido da dialética entre a 'paisagem' e o 'turismo' no que diz respeito a construção da paisagem de interesse turístico. Esta proposta tem como enfoque o espaço urbano compreendido como cenário de lazer.

\section{A construção da paisagem turística}

O turismo entendido como fenômeno social preconiza o deslocamento de pessoas para locais fora do seu entorno de origem com previsão de retorno. Tal deslocamento implica a utilização de serviços de uma determinada localidade como alojamento, alimentação, diversão, transporte, etc. (MORANDI; GIL, 2001). O turista, ator central do fenômeno tem como principal interesse o aspecto visual dos lugares e aquilo que estes têm de pitoresco, de diferente e atrativo aos sentidos (SILVA, 2004). O turismo na contemporaneidade, consumido em massa exige uma série de adaptações e criações de espaços para que a demanda turística seja atendida. A paisagem, portanto, sofre transformações radicais, o que atenua a cenarização e, portanto, uma tensão entre funções urbanas e o "espetáculo".

As paisagens podem ser entendidas como "testemunhos visuais de elementos estéticos e simbólicos construídos historicamente e que, quando identificados e apropriados pelo viajante, despertam um renovado interesse 
e contribuem para estabelecer uma valorização qualitativa" (SILVA, 2004, p.27). Segundo Morandi e Gil (2001), a paisagem possui "qualidades visuais" e propriedades que exercem forte atração sobre as pessoas. A paisagem urbana quando "bem composta", com um aspecto geral harmonioso, de construções bem conservadas, de ruas arborizadas, de praças e generosos jardins, "frequentemente são utilizadas para influenciar a escolha do turista em potencial' (SILVA, 2004, p.21).

Pode-se observar a importância da construção de paisagens que sejam atrativas aos turistas mas que também, ofereçam identidade ao lugar. Sobre este aspecto, Yázigi (2001) defende que a identidade local é acentuada "por todas as formas de construção arquitetônico-urbanística, com tudo que comportam em si" (p.49). Afirma também que a arquitetura pode ser entendida como o grande marco da paisagem e possui poder de acentuação da identidade local pelas formas de construção arquitetônicourbanística. Neste sentido, nota-se a responsabilidade das ações do poder público e privado, ou seja, da sociedade urbana como um todo, na construção das formas que compõem a paisagem local (YÁZIGI, 2001).

Em "Cidades Turísticas", Silva (2004) defende que as paisagens turísticas são cenários intencionalmente construídos e tem como objetivo reproduzir padrões de beleza e qualidade culturalmente estabelecidos, o que são versões de uma realidade idealizada". As cidades turísticas tendem a reproduzir paisagens existentes em outros lugares com 0 intuito de expressar um passado de colonização, como por exemplo, as cidades turísticas de cenário europeu, ou as "vilas europeias" como apelidou Silva (2004). São exemplos: Campos do Jordão/SP, Monte Verde/MG, Blumenau/SC e Gramado na Serra Gaúcha. Estas cidades ao incorporarem um estilo dito como "europeu" adotam uma identidade própria que as distingue das demais. Configuram, deste modo,

\begin{abstract}
Uma paisagem coerente com a ideia de lazer vendida pelo mercado, facilitando o processo de consolidação de uma determinada imagem. A tematização das cidades turísticas age, sobretudo, como meio de vendê-las como produtos comerciais: cria-se uma 'marca' de qualidade e distinção, facilmente reconhecível por turistas, moradores e pela própria indústria turística (SILVA, 2004, p. 23).
\end{abstract}

Embora Silva trate das cidades turísticas como toda a extensão urbana do município, Hayllar et al (2011) abordam que existem "distritos" dentro das cidades que são de maior interesse turístico. Trata-se da "área funcional turística". Segundo eles, a "área funcional" pode ser entendida como "Uma área geográfica distinta dentro de uma área urbana mais ampla, caracterizada por uma concentração de usos de solo dedicados ao turista, atividades e visitação, com fronteiras bastante definidas (HAYLLAR; GRIFFIN, 2005 apud HAYLLAR et al., 2011, p.4;5).

Os autores complementam Hayllar (et al.) esclarecendo que estas áreas podem incluir uma paisagem icônica, áreas de compras, instituições 
culturais de referência ou lugares de importância histórica e que tais áreas assumem uma identidade espacial, cultural, social e econômica particular (HAYLLAR et al., 2011). Mais propriamente sobre os cenários das áreas urbanas, eles afirmam que tais áreas oferecem cenários sociais, culturais, físicos e estéticos que podem ser apropriados pela atividade turística. Ainda, ressaltam que "a estética e a cultura da cidade e seus moradores é o que saúdam os visitantes" (HAYLLAR et al., 2011, p.3).

Ainda sobre a importância da paisagem para o turismo, Urry (2001), em sua obra "O olhar do turista" destaca que o fato que o olhar dos turistas é direcionado para os aspectos da paisagem que lhes são diferentes da experiência de todos os dias. Desta forma, o olhar do turista busca os signos do lugar em que se encontra. Urry reforça a ideia ao citar Culler (1981): "o turista se interessa por tudo como um sinal da coisa em si [...] os turistas, se inflamam, à procura dos sinais das demonstrações do francesismo, do comportamento italiano típico, de cenas orientais exemplares, de autopistas americanas típicas, de pubs tradicionais ingleses" (CULLER apud URRY, 2001, p.18).

A construção das paisagens turísticas é um processo que pode ser entendido a partir de duas perspectivas. De um lado, estão as intervenções urbanísticas pelo poder público e privado e por meio da arquitetura; do outro, os meios de comunicação que veiculam as imagens e descrevem os lugares e incentivam o imaginário social. (SILVA, 2004). Neste sentido, Bessa (2011) afirma que os "projetos turísticos de paisagem" podem ser entendidos a partir da ação estatal, dos discursos dos marcos regulatórios "criados para oficializar os projetos de intervenção. Leis, decretos, portarias, discursos podem revelar as intenções e ações do Estado em determinado projeto de intervenção" (BESSA, 2011, p.75).

Além disso, os "projetos turísticos" podem ser entendidos por meio de mapas turísticos e materiais de divulgação de produtos turísticos uma vez que estes apresentam as intenções do poder público para estes projetos (BESSA, 2011). Yágizi é crítico enquanto a tematização das cidades turísticas e afirma que "é preciso buscar um desenho que reflita o pluralismo cultural", e reforça a ideia de Rapoport (1978 apud YÁZIGI 2001): "se a forma urbana é uma expressão da cultura, e a paisagem cultural urbana e a cidade são uma série de áreas com variadas personalidades culturais e subculturais, o desenho então deve responder a isso" (p.234).

Além disso Yázigi complementa criticando o resgate do "típico" na cenarização das cidades turísticas, dizendo que é preciso "que se resguarde da tentação alienante de acentuar o 'típico' de cada cultura, congelada no tempo. Os grupos estão (e não são). Suas afirmações oscilaram muito mais para a criatividade do que para a secularização" (YÁZIGI, 2001, p.235) E conclui "A questão da identidade (no caso, sua marca no espaço) não poderá ser equacionada pela via folclórica-turística, caminho que seduz comerciantes e desavisados. É preciso que se entenda sempre as mudanças no meio ambiente como uma relação social' (CASTELLS, 1972 apud YÁZIGI, 2001, p.238).

Conclui-se, portanto, que as paisagens turísticas são construídas socialmente e tem como intuito a caracterização dos lugares orientada para 
compreender interesses do poder público e da sociedade; como marco de uma identidade própria ao território e como produto do turismo. A discussão sobre esta temática pode apresentar prós e contras nos mais diversos sentidos. É uma questão complexa a ser tratada e ainda como explicita Yázigi (2001, p.288), "Concordar com a espetacularização permanente da cultura, como é norma hoje em dia, é trabalhar para que a alienação aumente. Mas não creio que este seja um problema do turismo, mas de toda a civilização".

Neste referencial teórico, abarcou-se o conceito da paisagem turística de forma ampliada ao turismo e à geografia, pois, este tema apresenta uma variedade de especificações relativas a ele, como foram citados: 0 imaginário social construído da paisagem; a paisagem turística de cenário; o olhar do turista para a paisagem; e as influências do poder público e privado e da sociedade na construção histórica de um determinado espaço.

\section{O urbanismo}

A partir do deslocamento da produção agrícola para a produção industrial no momento que marca o início da era moderna, a sociedade em geral acompanhou a mudança nos padrões de vida e trabalho, do campo para as cidades. A relação "cidade-campo" que impõe a importância da cidade sobre o campo, a partir da teoria da divisão do trabalho intelectual e manual, segundo Marx e da centralidade e importância do mercado, segundo Weber, é um dos fatos que marcam a sociedade capitalista industrial (MONTE-MÓR, 2006). Neste sentido, a cidade entendida como o novo espaço do trabalho e comércio,

Logo se caracterizou como espaço precípuo do poder, da festa cultural, das trocas e concentração do excedente produtivo. Logo também se constituiu como a centralidade da comunidade organizada, onde se encontram as instituições, leis e mecanismos de gestão, serviços religiosos e manifestações culturais, monumentos, trocas no mercado e serviços coletivos de apoio à vida quotidiana (MONTE-MÓR, 2006, p.186).

Desta forma, entende-se que o campo e a cidade têm uma relação antagônica, mas complementar uma vez que o campo é o espaço circundante a esta centralidade que caracteriza as cidades. Deste modo, o conceito de município desenvolve-se a partir desta relação que unifica ambas partes em uma só unidade urbano-rural. Cada vez mais a partir da era industrial, as cidades se tornavam o centro da organização da sociedade e da economia, combinando o espaço da vida produtiva e o território da produção industrial (MONTE-MÓR, 2006).

O surgimento do "urbano" está intrínseco ao processo de evolução das cidades defendido pelo filósofo francês Henri Lefebvre (1969; 1999 apud MONTE-MÓR, 2006). Este processo caracteriza-se fundamentalmente pela 
dinâmica centralizada nas cidades ao longo do tempo histórico. Inicia-se a partir da "cidade política" em que esta exerce seu domínio político sobre o campo. Logo, a "cidade mercantil" resulta da entrada de uma burguesia neste espaço trazendo consigo o mercado, e por conseguinte, a inflexão econômica, e não somente político ideológica da cidade sobre o campo (MONTE-MÓR, 2006).

A ocorrência do "urbano" surge a partir da inserção da indústria na cidade. A cidade como centro da produção, também tornou-se o centro do consumo e da vida. Com as industrias vieram os proletários, a população consumidora e as "condições gerais de produção. Houve, desta forma, um inchaço populacional e industrial que gerou a expansão do tecido urbano, a "explosão" como afirma Lefebvre (1999 apud MONTE-MÓR, 2006). O urbano neste sentido, é entendido como a extensão da cidade ao espaço regional imediato que carrega consigo a forma e o processo socioespacial e as condições gerais de produção. Segundo Monte-Mór:

Espaço urbano é esse 'tecido' que nasce nas cidades e se estende para além delas, sobre o campo e as regiões, uma síntese da antiga dicotomia cidade campo, um terceiro elemento na oposição dialética cidade-campo, uma manifestação material e socioespacial da sociedade urbanaindustrial contemporânea estendida, virtualmente, por todo espaço social (MONTEMÓR, 2006, p.190).

A tomada do espaço social das cidades pela lógica da industrialização ocorre não somente a partir da presença das industrias e do proletariado, mas também, a partir da despolitização do espaço social. "A divisão técnica do trabalho da fábrica foi transportada para a divisão social no espaço de vida urbana, estendendo a lógica produtiva ao espaço cultural e político que marcava a cidade" (MONTEMÓR, 2006, p.190).

Na década de 1970, o filósofo francês deslumbrou o ressurgimento da importância das funções sociais que as cidades detinham anteriormente à subordinação industrial. "O Direito à Cidade", uma de suas maiores obras, traz o questionamento acerca da fragmentação funcional da totalidade da cidade que separou os espaços do poder, aos espaços da habitação, da cultura e do lazer fazendo com que os proletários e pobres fossem expulsos dos centros e alocados nas periferias (MONTE-MÓR, 2006).

O urbanismo visto como prática social é assim considerado desde o surgimento das cidades, ou seja, a pelo menos cinco mil anos. Foi essencialmente, a partir da necessidade de se resgatar as práticas sociais às cidades, que o urbanismo como campo de estudo tomou impulso sobretudo no final do século XIX quando formulou um arcabouço teórico e uma estrutura disciplinar própria (SCHERER apud YÁZIGI, 2002). Segundo YÁZIGI (apud SOUZA, 2002, p. 112) a urbanística (como disciplina) "é um ramo da política, de caráter multidisciplinar, que organiza a cidade em seus aspectos físicos em consonância, com as relações sociais, produtivas e culturais". O urbanismo segundo ele, seria o produto da urbanística. Esta 
disciplina seria a articulação de uma série de saberes que contribuiriam para o urbano, que teria que contar:

a) Com a organização espacial dos meios de produção;

b) com as previsões da demografia para fins de suprimento de equipamentos e serviços; c) com a engenharia, na feitura de viadutos, tubulações, tubulações subterrâneas, sistema viário, transportes, iluminação etc.; d) com arquitetura, nas edificações em geral, no mobiliário urbano etc.; e) com artes maiores e menores, nos monumentos, acabamentos, adornos; f) com a botânica, nos parques urbanos, arborização linear etc.; g) com a ecologia, enquanto gerenciamento de ciclos genéticos; h)com o paisagismo, na organização estética de conjuntos construídos ou naturais; i) com a identidade espacial do lugar, esta última, de importância fundamental para o turismo (YÁZIGI apud SOUZA, 2002, p. 112).

Para Mazzaroli (apud MUKAI, 2007) o urbanismo, do ponto de vista técnico é "a ciência que se preocupa com a sistematização e desenvolvimento da cidade buscando determinar a melhor posição das ruas, dos edifícios e obras públicas, de habitação privada de modo que a população possa gozar de uma situação sã, cômoda e estimada" (p.13). Segundo Mukai (2007), a definição de urbanismo mais recentemente passou a visar o homem no contexto urbano e a melhoria das suas condições de vida. Nesta linha, as políticas urbanas, a partir da Constituição Federal Brasileira, art. 182, caput, trouxeram em legislação permanente, os caminhos para traçar as "diretrizes gerais" que objetivam o pleno desenvolvimento das funções sociais da cidade (CARNEIRO, 1998).

A migração do rural para o urbano sempre foi uma mudança abrupta e sem qualquer organização. As cidades, salvo algumas poucas, nunca foram planejadas adequadamente para receber as populações que vivem nelas (CARNEIRO, 1998). A população, segundo Huberman (apud CARNEIRO, 1998), queria a liberdade de ir e vir quando lhe melhor conviesse, queria a liberdade pelos apelos da cidade, a busca por uma nova vida (CARNEIRO, 1998).

Diante disto, os Estados visando garantir à sociedade seus direitos à cidade (LEFEBVRE, 2001) e o direito à propriedade (MUKAI, 2007; CARNEIRO, 1998) a partir da Democracia, instituíram em suas Constituições as normas urbanísticas que norteariam as diretrizes para garantir tais direitos. No Brasil, a partir da Constituição da República Federativa do Brasil, de 05 de outubro de 1988, instituíram-se as diretrizes "com o objetivo final de cuidar dos procedimentos desapropriatórios com finalidades urbanísticas" (CARNEIRO, 1998, p. 16). 
A Política Urbana no Brasil se destrincha entre os âmbitos do Poder Público: municípios, estados e União. Compete a cada uma das instancias o ordenamento do território a partir de seus propósitos próprios, mas em consonância entre os objetivos gerais (CARNEIRO, 1998).

Para este estudo, não se faz necessário o aprofundamento da política urbanística que diz respeito aos Estados e a União, mas assegura-se a importância destes para as diretrizes do Poder Público municipal no que se refere aos planos urbanísticos.

Desta forma, dá-se prosseguimento ao arcabouço teórico deste estudo com a introdução da Legislação Urbanística municipal e seus instrumentos de ordenação territorial com vista a compreendê-los e mais adiante analisá-los em relação ao desenvolvimento do turismo a partir destas políticas.

\section{Diretrizes de fomento ao turismo: urbanização turística}

Para a atividade turística, as diretrizes urbanísticas podem influenciar sobremaneira no modo em que esta atividade é praticada. Para Yázigi (apud SOUZA, 2002) é praticamente impossível praticar turismo sem bases urbanas. Ele considera que a atividade pode ser prejudicada ou beneficiada pelo urbanismo e que requer deste "um meio de desabrochamento humano ao mesmo tempo agradável e diferenciado, isto é, com identidade própria" (YÁZIGI, apud SOUZA, 2002, p.113). Para Luchiari (2000):

A urbanização turística tende a introduzir, nos lugares, cenários significativos do imaginário urbano moderno. Estes signos - representados na infraestrutura, na estética arquitetônica, nos objetos de consumo - proporcionam aos turistas a superação do estranhamento ao meio social e natural local, mas implantam, muitas vezes, uma materialidade que não se comunica com 0 lugar. (LUCHIARI, 2000, p.39).

Yázigi ainda afirma que geralmente haverá partes de um território mais atrativas à população ou ao turismo. É o que se pode chamar de destaques do urbanismo. "Nessa hipótese duas advertências são necessárias: a) precaução em não falsear os destaques com meras maquiagens e, b) simultaneamente, através da política urbana, elevar o nível ambiental das periferias, diminuindo assim o vergonhoso contraste entre elas e os centros" (YÁZIGI, apud SOUZA, 2002, p.116).

Desta forma, pode-se considerar as cidades turísticas são uma nova forma de urbanização, pois são construídas para o consumo de bens, serviços e paisagens. Algumas destas cidades redefinem suas vidas econômicas em função do desenvolvimento da atividade turística, focando seus esforços para produzir paisagens atrativas para o lazer e o consumo (LUCHIARI, 2000, p.2).

Este processo pode caracterizar o que chama atenção Scherer (apud YÁZIGI, 2002) em relação ao valor que paisagens urbanísticas tem para o 
setor do turismo, pois a beleza, a harmonia dos elementos, o pitoresco das diferentes paisagens sempre encantou e continua a encantar turistas. Ainda sobre esse processo 0 autor destaca que a paisagem urbanística transformou as cidades em mercadorias que se vendem a eventos, turismo, espetáculos de massa, etc., que beneficiam o turismo, mas, mais do que isso, se tornaram um elemento estratégico para o capital financeiro (SCHERER, apud YÁZIGI, 2002).

Diante desta explanação teórica, pode-se concluir que as políticas urbanísticas mediadas pelo poder público municipal podem ser utilizadas pelo setor turístico para criar ambientações, paisagens, identidades locais que influenciam entre outros aspectos, a vida dos moradores locais, a experiência dos turistas, a garantia da função social nas cidades.

\section{Legislação urbanística municipal brasileira}

É a partir da Constituição da República Federativa do Brasil, de 1988, que se baseiam as Políticas Urbanísticas vigentes hoje no território nacional. Como abordado, cada instancia do poder público tem, a partir deste documento, suas competências em relação ao zelo, cuidado, proteção, fomento e combate às diversas instancias da vida social na Democracia. Segundo Artigo 23 da Constituição Federal de 1988 (apud MUKAI, 2007, p. 223-224), é competência comum da União, dos Estados, do Distrito Federal e dos Municípios:

I- zelar pela guarda da Constituição, das leis e das instituições democráticas e conservar o patrimônio público;

II- cuidar da saúde e assistência pública, da proteção e garantia das pessoas portadoras de deficiência;

III- proteger os documentos, as obras e outros bens de valor histórico, artístico e cultural, os monumentos, as paisagens naturais notáveis e os sítios arqueológicos;

IV- impedir a evasão, a destruição e a descaracterização de obras de arte e de outros bens de valor histórico, artístico ou cultural;

V- proporcionar os meios de acesso à cultura, à educação e à ciência;

VI- proteger o meio ambiente e combater a poluição em qualquer de suas formas;

VII- preservar as florestas, a fauna e a flora;

VIII- fomentar a produção agropecuária e organizar o abastecimento alimentar;

IX- promover programas de construção de moradias e a melhoria das condições habitacionais e de saneamento básico;

X- combater as causas da pobreza e os fatores de marginalização, promovendo a integração social dos setores desfavorecidos; 
$\mathrm{XI}$ - registrar, acompanhar e fiscalizar as concessões de direitos de pesquisa e exploração de recursos hídricos e minerais em seus territórios;

XII- estabelecer e implantar política de educação para a segurança do trânsito.

Parágrafo único. Lei complementar fixará normas para a cooperação entre a União e os Estados, o Distrito Federal e os Municípios, tendo em vista o equilíbrio do desenvolvimento e do bem-estar em âmbito nacional

Tais competências são as diretrizes gerais da Constituição sobre as obrigatoriedades dos âmbitos públicos válidos a todo território nacional. Além do artigo supracitado, torna-se mais relevante para o prosseguimento deste estudo, dizer sobre a política urbana que, baseia suas competências ao Poder Público municipal no que diz respeito a execução das diretrizes. Sendo assim, o Capítulo II da Constituição Federal de 1988, traz o Artigo 182 sobre a Política Urbana que diz:

A política de desenvolvimento urbano, executada pelo Poder Público municipal, conforme diretrizes gerais fixadas em lei, tem por objetivo ordenar o pleno desenvolvimento das funções sociais (grifado próprio) da cidade e garantir o bem-estar de seus habitantes.

$\S 1^{\circ}$ - O plano diretor, aprovado pela Câmara Municipal, obrigatório para cidades com mais de vinte mil habitantes, é o instrumento básico (grifado próprio) da política de desenvolvimento e de expansão urbana.

$\S 2$ - A propriedade urbana cumpre sua função social quando atende às exigências fundamentais de ordenação da cidade expressas no plano diretor.

$\S 3^{\circ}$ - As desapropriações de imóveis urbanos serão feitas com prévia e justa indenização em dinheiro.

§ 4ํ - É facultado ao Poder Público municipal, mediante lei específica para área incluída no plano diretor, exigir, nos termos da lei federal, do proprietário do solo urbano não edificado, subutilizado ou não utilizado, que promova seu adequado aproveitamento, sob pena, sucessivamente, de:

I- parcelamento ou edificação compulsórios;

II- imposto sobre a propriedade predial e territorial urbana progressivo no tempo;

III- desapropriação com pagamento mediante títulos da dívida pública de emissão previamente aprovada pelo Senado Federal, com prazo de resgate de até dez anos, em parcelas anuais, iguais e sucessivas, assegurados o valor real da indenização e os juros legais (CONSTITUIÇÃO FEDERAL, 1998 apud MUKAI, 2007, Anexo I, p. 225-266). 
Neste momento, se vê a expressiva contribuição repassada ao "Plano Diretor" no ordenamento territorial dos municípios. Este documento é o instrumento básico da política de desenvolvimento dos municípios brasileiros. A Lei Federal $n^{\circ} 10.257$, de 10 de julho de 2001, regulamenta os artigos 182 e 183 da Constituição Federal e estabelece o "Estatuto da Cidade" cujas "normas de ordem pública e interesse social [...] regulam o uso da propriedade urbana em prol do bem coletivo, da segurança e do bem-estar dos cidadãos, bem como do equilíbrio ambiental'.

Não cabe aqui exprimir todas as diretrizes deste documento, mas sim entende-lo como lei primordial ao desenvolvimento urbano municipal e mais do que isso, compreender os instrumentos da política urbana que acompanham os objetivos propostos por esta lei.

O Plano diretor é o principal instrumento de ornamento territorial urbano da política pública brasileira, este documento surgiu a partir da promulgação do Estatuto da Cidade Lei Federal nํㅜ 10.257 de 10 de julho de 2001. De modo geral, o objetivo proposto pelo Plano diretor é de fazer com que a função social da propriedade urbana seja cumprida a partir das exigências fundamentais de ordenação territorial previstas na mesma lei (MUKAI, 2007).

O Plano diretor como principal instrumento de gestão urbanística, engloba outras diretrizes existentes na política urbana: o plano plurianual, as diretrizes orçamentárias e o orçamento anual, segundo $\$ 1^{\circ}$ do Artigo 40 do Estatuto das Cidades (MUKAI, 2007). Segundo Artigo 41 do documento supracitado, o Plano diretor é obrigatório para cidades:

I- com mais de vinte mil habitantes;

II- integrantes de regiões metropolitanas e aglomerações urbanas;

III- onde o Poder Público municipal pretenda utilizar os instrumentos previstos no $\S 40$ do art. 182 da Constituição Federal;

IV- integrantes de áreas de especial interesse turístico;

V- inseridas na área de influência de empreendimentos ou atividades com significativo impacto ambiental de âmbito regional ou nacional.

VI- incluídas no cadastro nacional de Municípios com áreas suscetíveis à ocorrência de deslizamentos de grande impacto, inundações bruscas ou processos geológicos ou hidrológicos correlatos (LEI № 10.257 de 10 de julho de 2001).

O plano diretor, segundo incisos $2^{\circ}$ e $3^{\circ}$ do Artigo 40 do Estatuto da Cidade, engloba tanto áreas rurais quanto áreas urbanas dos municípios e garante que a lei que instituir o plano deverá ser revista, pelo menos a cada dez anos (LEI № 10.257/01 apud MUKAI, 2007). 
Além do Plano Diretor, outros instrumentos de Política Urbana são de grande relevância para ordenamento territorial urbano como a disciplina do parcelamento, do uso e ocupação do solo. Assim como o Plano diretor, tais instrumentos são determinados por Leis Federais podendo o município implantar lei complementar que adicione "o previsto nesta Lei às peculiaridades regionais e locais"

É palpável constatar, a partir do que foi abordado anteriormente sobre a paisagem neste referencial teórico, que as diretrizes urbanísticas tenham um papel de grande relevância na construção da paisagem das cidades uma vez que ordenam, isto é, criam normas intencionais (SANTOS apud ALMEIDA; SOARES, 2009) sobre o território de maneira a influenciar a disposição dos objetos espaciais. Não obstante, delimita os espaços, e portanto, as funções sociais.

Neste sentido, direciona-se este referencial para uma questão que permeia paisagem e urbanismo mas dá propriedade ao turismo. A urbanização turística é um conceito trabalhado por diversos autores como fruto da pós-modernidade e das novas dinâmicas sociais que se traduzem no âmbito urbano.

\section{Holambra: dos tempos de colônia e emancipação}

Após a Segunda Guerra Mundial que assolou a Europa, dominada pelos exércitos nazistas entre 1939 e 1945, muitas famílias tinham em vista uma vida cheia de incertezas e reconstruções. Muitos haviam perdido suas casas, seus parentes e buscavam em meio a tanta destruição uma nova maneira de viver. A Holanda, atacada primeiramente em 1940, tinha uma grande parcela da população vivendo da agricultura e da pecuária nos campos.

O Brasil e a França foram naquela época, países que aceitavam firmar acordos internacionais de migração. Estes dois, aceitavam imigrações em grupos, na possibilidade de formar colônias. Foi neste momento que uma associação de agricultores católicos da província de Limburgo, na Holanda decidiu investigar a possibilidade de migrar grupos de famílias inteiras para o Brasil, onde estas famílias pudessem se instalar e criar, portanto, uma colônia de agricultores católicos.

Passaram alguns anos até que a vinda ao Brasil se concretizasse e as famílias pudessem enfim migrar em destino a Fazenda Ribeirão, localizada entre os municípios de Campinas e Mogi-Mirim no interior paulista. Foi em 1948 quando as primeiras famílias puderam se instalar na Fazenda comprada para o "Projeto Holambra". A imigração perdurou aproximadamente cinco anos.

Como forma de legitimar a instalação da Fazenda Ribeirão, nesta época pertencente a cinco distintos municípios circundantes a Fazenda, criou-se a Cooperativa Holambra como forma legal de assentamento e início das atividades agrícolas e pecuárias no local. Neste início, todos os chefes de família deveriam se afiliar à Cooperativa assim que chegassem em terras brasileiras, como forma de garantir os fundos da mesma e poder instalar as primeiras construções de uso coletivo. A economia da fazenda se baseava 
na produção de leite a partir do gabo de raça pura holandesa que os colonos haviam trazido nos navios. A produção se comercializaria em Campinas/SP. Nos primeiros anos, os colonos tiveram grandes problemas principalmente, porque o gabo contraiu doenças tropicais e desta forma, a produção de laticínios caia incessantemente.

A Cooperativa Holambra faliu. O modelo econômico não agradava a maioria dos fazendeiros que em decisão conjunta decidiram desmembrar a cooperativa e os lotes da fazenda. Cada um em seu lote, produzia o que melhor lhe viesse financeiramente e os produtos destas fazendas seriam destinadas às novas repartições da Cooperativa que os venderia. Foi com a vinda de alguns bulbos de gladíolos trazidos da Holanda por um colono que, a produção de flores e plantas em Holambra representou o início de uma nova fase de prosperidade para os holandeses. O mercado da região aceitou bem as flores que eram vendidas em Campinas e deste modo, mais tarde, muitos outros fazendeiros optaram pelo cultivo de flores e plantas ornamentais como principal ativo econômico.

A expansão do setor foi rápida, a cooperativa criou uma divisão para flores e plantas assim como armazéns para a estocagem, a compra de caminhões para entregas, entre outras melhorias. Os holandeses em Holambra sempre estiveram em contato com seus parentes e amigos na Holanda o que possibilitou a transferência de tecnologias e maquinários para o cultivo das flores.

Na década de 1980, Holambra ainda era uma fazenda com certo distanciamento dos outros centros urbanos próximos. A vida em Ribeirão era pacata, promissora, com aspecto rural. A venda das flores e plantas logo atingiu mercados maiores como São Paulo e Rio de Janeiro, entre outras cidades do Brasil e da América do Sul. Foi no final da década de 1980 que, com a expansão do mercado de flores e a abertura econômica da cidade, que os primeiros problemas sociais começaram a surgir como a falta de segurança, saúde e vias de acesso.

Em 1982, portanto, criou-se a Comissão para assuntos urbanos de Holambra, em que se decidiu que a melhor solução encontrada para os problemas que atingiam a fazenda, era sua emancipação. Holambra pertencia a cinco municípios, como supracitado, e este representava um empecilho político uma vez que não se permitia a elevação de categoria de fazenda a município sem esta ser antes, um distrito. O esforço do governo estadual em modificar o artigo 34 do Ato das Disposições Constitucionais Transitórias da Construção do Estado de São Paulo de 5 de outubro de 1989 daria condições para que Holambra e diversos municípios se emancipassem. Foi, portanto, em 27 de outubro de 1991 que Holambra realizou seu primeiro Plebiscito com 2.525 eleitores que aprovaram com 98\% dos votos, a emancipação de Holambra (Figura 1). 


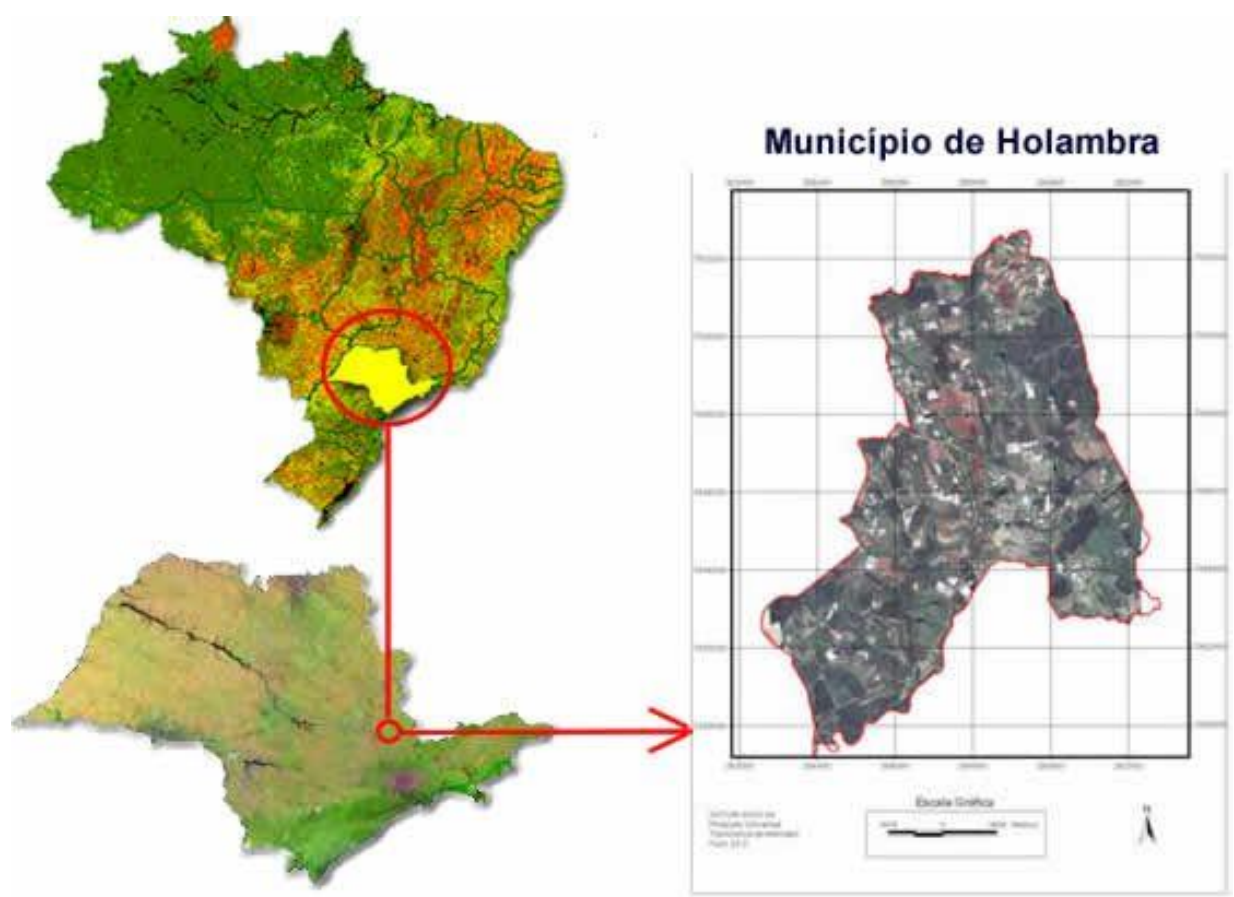

Figura 1: Localização do município de Holambra/SP.

Figure 1: Location of the municipality of Holambra / SP.

Fonte: Embrapa. Disponível em: http://www.holambra.cnpm.embrapa.br/hloca.html. Acesso em: 18/05/2015

Source: Embrapa. Available at: http://www.holambra.cnpm.embrapa.br/hloca.html. Accessed on: 05/18/2015

O principal motivo pelo qual, Holambra tornou-se um município, como mencionado, foi devido os problemas de segurança que o assolavam. Com a pavimentação das principais vias de acesso, Holambra perdeu seu quase isolamento com os municípios da região e, portanto, teve que estruturar-se enquanto ao seu corpo de segurança. Consequência deste desenvolvimento, foi a perda substancial da tranquilidade da vida na excolônia, e a característica das casas e do comércio que tenderam a se proteger cada vez mais, ainda que, haja exemplos pelo centro na atualidade.

$O$ desenvolvimento urbano observado em Holambra a partir de sua emancipação, e consequente abertura da antiga colônia a novos negócios, fez com que novos postos de trabalho surgissem, e, portanto, novos moradores. A emancipação trouxe o desenvolvimento do tecido urbano ${ }^{7}$, assim como a diversificação dos serviços e o aumento populacional.

Paralelamente a expansão do mercado de flores e plantas, em 1983, por iniciativa da Cooperativa de Flores Holambra, deu-se o início de uma feira anual de exposição das flores e plantas produzidas pelos fazendeiros holambrenses. A feira, com o passar dos anos, ganhou a atenção de curiosos e interessados no tema. Com o tempo, expandiu-se e incorporou novas atratividades e serviços aos visitantes. Tais atrativos traziam aos visitantes comidas tradicionais, danças típicas e lembranças da feira. Estes elementos, por sua vez, estavam carregados de símbolos e costumes da cultura holandesa trazida por aqueles que moravam em Holambra.

A festa ganhou um caráter mais "típico" holandês, sem perder 0 destaque para as flores e plantas. Deste modo, a festa ampliou-se, a 
cooperativa não obteve maiores interesses em continuar e a ideia foi comprada por empresários privados, e até a atualidade se configura desta maneira. Hoje, a Expoflora em Holambra, recebe anualmente cerca de 300.000 visitantes no mês de setembro e apresenta aos que a visitam, um recinto com construções em estilo holandês, comidas típicas, danças típicas, o mercado de flores e plantas e ainda, uma exposição de paisagismo e decoração e inúmeros quiosques com os mais diversos produtos como sapatos, bolsas, utilidades domésticas, etc.

Com a expansão da festa no início da década de 1990 e a urbanização de Holambra, os motivos holandeses utilizados nas construções dentro do recinto da Expoflora, ultrapassaram estes limites e aproveitaram o momento do desenvolvimento urbano para criar um cenário de lazer voltado à cenarização da cidade como "um pedacinho da Holanda no Brasil", como atualmente é conhecida.

\section{Política urbanística e turismo}

A cenarização ${ }^{8}$ direcionada ao desenvolvimento da atividade e atratividade turística que se deu em Holambra surgiu, a partir de duas iniciativas, como mencionado: a política de abono no I.P.T.U. municipal para as edificações que tivessem suas fachadas ornamentadas com os motivos holandeses e ainda, o surgimento desta característica arquitetônica holandesa dentro do recinto da Expoflora. É possível considerar que, estes dois eventos foram postos em prática quase que concomitantemente, sendo que a ideia implantada no recinto, influenciou a política que expandiria este movimento para o tecido urbano que se desenvolvia.

Desta forma, desde o início da década de 1990, a paisagem urbana de Holambra apresenta em sua extensão, mas com uma certa centralidade, elementos físicos da cultura holandesa que são representados nas diversas fachadas de edifícios comerciais e em menor número residenciais, em pequenos moinhos de vento, nos atrativos turísticos como o "Portal de Holambra" e o "Moinho Povos Unidos", nos restaurantes que explicitam os pratos "típicos" e nas lojas de souvenir que vendem tamancos de madeira e a porcelana importada de Delft, Holanda.

A paisagem urbana local, portanto, oferece um aspecto pitoresco e remete, sempre que pode, a um cenário europeu quase sempre elitizado (Figura 2), apresentando áreas verdes de uso coletivo, cenários que reúnem lagos, pequenas vegetações, uma urbanização controlada, com certa limpeza urbana e charme. Ainda, existem algumas residências localizadas, principalmente, no centro histórico que são próprias de famílias imigrantes e apresentam uma uniformidade estrutural e arquitetônica condizentes à época da colônia holandesa e configuram um atrativo da paisagem pois são casas em lotes grandes (variam entre 2 mil e 4 mil metros quadrados), com jardins bem ornamentados com vistas para o Lago Vitória Régia. Estaria no imaginário do turista este modo de vida em Holambra? 


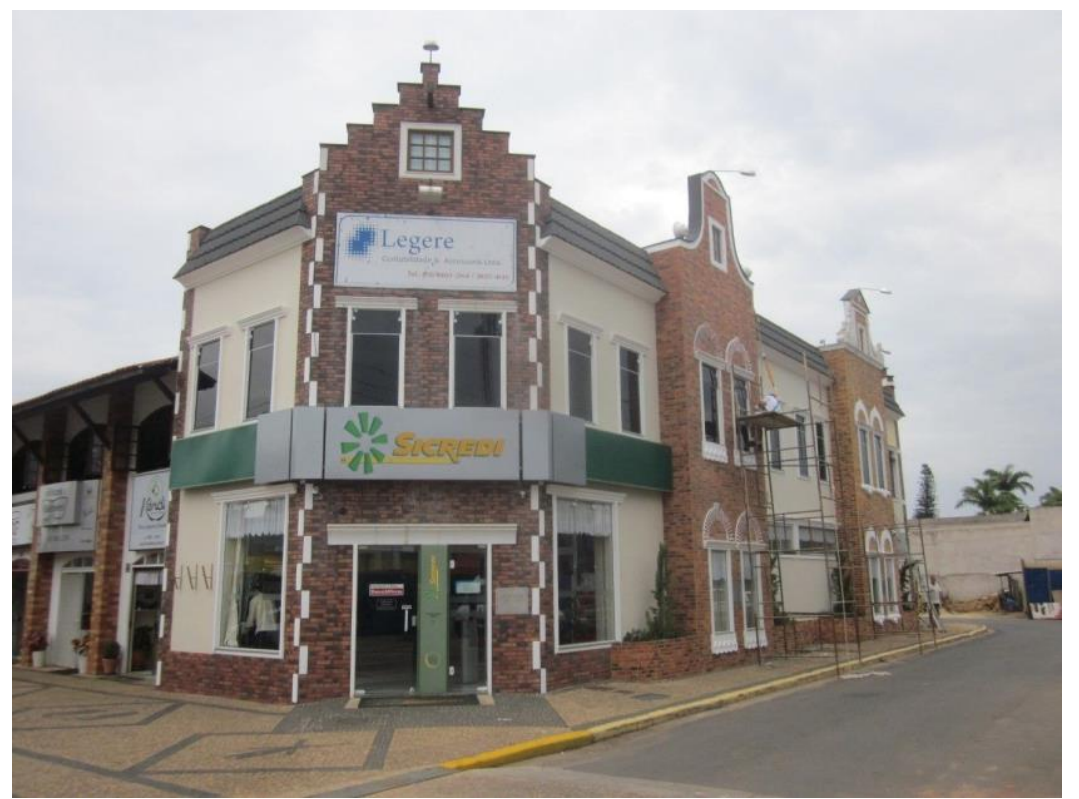

Figura 2: Fachada holandesa no centro de Holambra. Fonte: Arquivo pessoal.

Figure 2: Dutch facade in the center of Holambra. Source: Personal archive

Os estudos realizados na monografia mostraram que grande parte das intervenções urbanísticas e construção dos atrativos turísticos somente foram possíveis graças aos investimentos provindos de sua condição de Estância Turística, recursos estes provenientes do Departamento de Apoio ao Desenvolvimento das Estâncias (Secretaria de Turismo do Estado de São Paulo). Sendo assim, pode-se afirmar que as políticas urbanísticas representam papel de fundamental importância no desenvolvimento do turismo em Holambra.

Foi uma decisão política, portanto, que Holambra como cidade começou a investir na sua "identidade" que serviria mais tarde como atrativo ao turismo. Esta decisão logrou seu objetivo. Hoje em dia, Holambra é uma cidade turística que tenta, a todo instante ser lembrada como o "pedacinho da Holanda no Brasil" tendo refletido esta sensação na arquitetura "típica", na gastronomia, no nome dos logradouros públicos, nos empreendimentos turísticos ou não, e na vida social como um todo. É claro, os holandeses e descendentes que ainda moram em Holambra podem sentir a cada dia que "sua cultura" está a todo momento representada e é responsável pela cidade pacata, tranquila e charmosa que Holambra pode se vangloriar e diferenciarse das demais cidades. É isso que alimenta o ego local, o turismo, o mercado imobiliário, etc.

Diante desta decisão, que fez com que Holambra tomasse o caminho rumo ao desenvolvimento turístico que se propunha e ao desenvolvimento urbano que se alcançava, existia uma Holambra que aos poucos desaparecia em meio ao aumento do número de automóveis, lojas, novos condomínios e bairros inteiros. A sede da ex-colônia de holandeses localizada ainda em propriedade da Cooperativa Holambra, na região central da cidade, foi o palco das reuniões e eventos que aconteciam na colônia. Este espaço incluía a "Igreja Velha", uma paineira que marcava o espaço 
central destes encontros, a "Escola São Paulo", primeira escola infantil de Holambra, em que os filhos dos holandeses eram alfabetizados em português. Estes locais, primórdios da fundação da colônia holandesa, estão hoje caídos no esquecimento da Cooperativa Holambra e da Prefeitura Municipal uma vez que estão em estado de abandono. A antiga "Escola São Paulo", hoje, de propriedade pública, sob gestão da Prefeitura Municipal está também em abandono e é depósito deste órgão público (Figura 3).

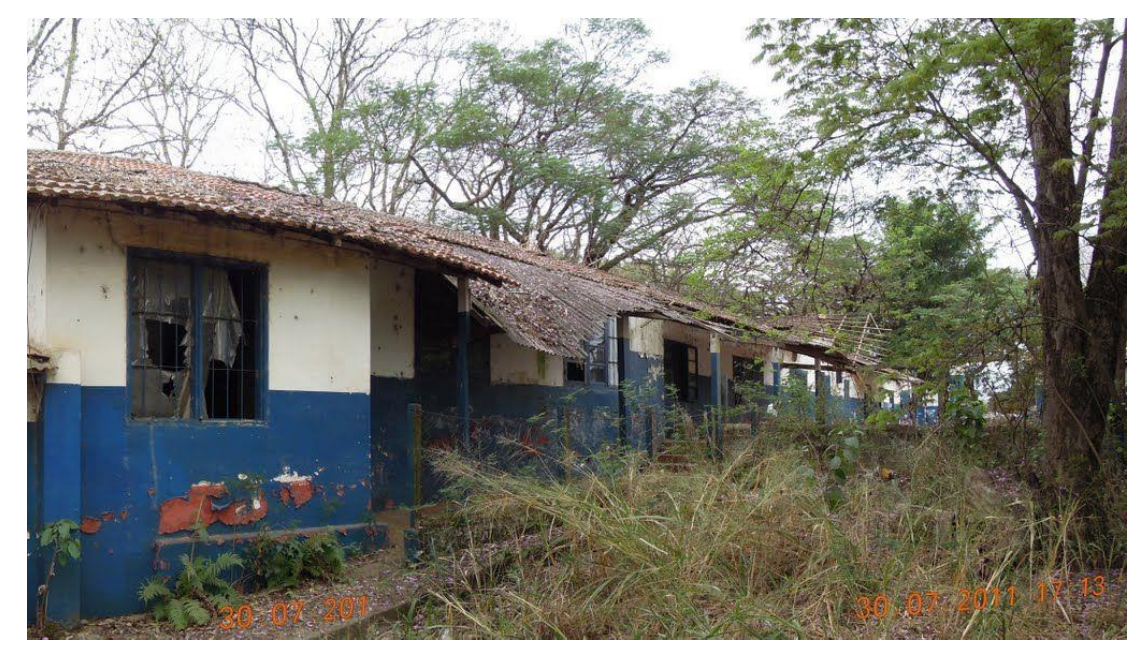

Figura 3: Antiga Escola São Paulo em estado de abandono.

Figure 3: Old São Paulo School in a state of abandonment.

Fonte: http://br.worldmapz.com/photo/93155 pt.htm. Acesso em: 22/05/2015.

Source: http://worldmapz.com/photo/93155_en.htm. Accessed on: 05/22/2015.

Além disso, outro edifício público, mantido pela Prefeitura Municipal, a Casa de Charles Hogenboom, ex-presidente da Cooperativa Holambra ainda na época da colônia, é uma das principais construções desta época que, já havia sido descaracterizada e em 2014 sofreu uma reforma, com investimento provindo do DADE (Secretaria de Turismo do Estado de São Paulo), sendo ainda mais descaracterizada, perdendo-se quase que por completo suas características originais

A veiculação, infelizmente não gerou nenhum tipo de modificação na reforma ou repercussão em órgãos oficiais da área do patrimônio histórico e artístico. A casa teve os pilares da varanda revestidos por azulejos de cor laranja (cor oficial da gestão municipal), assim como suas janelas e portas. A reforma da casa acompanhou a reforma da Praça dos Pioneiros, localizada no bairro Centro (Figura 3). 


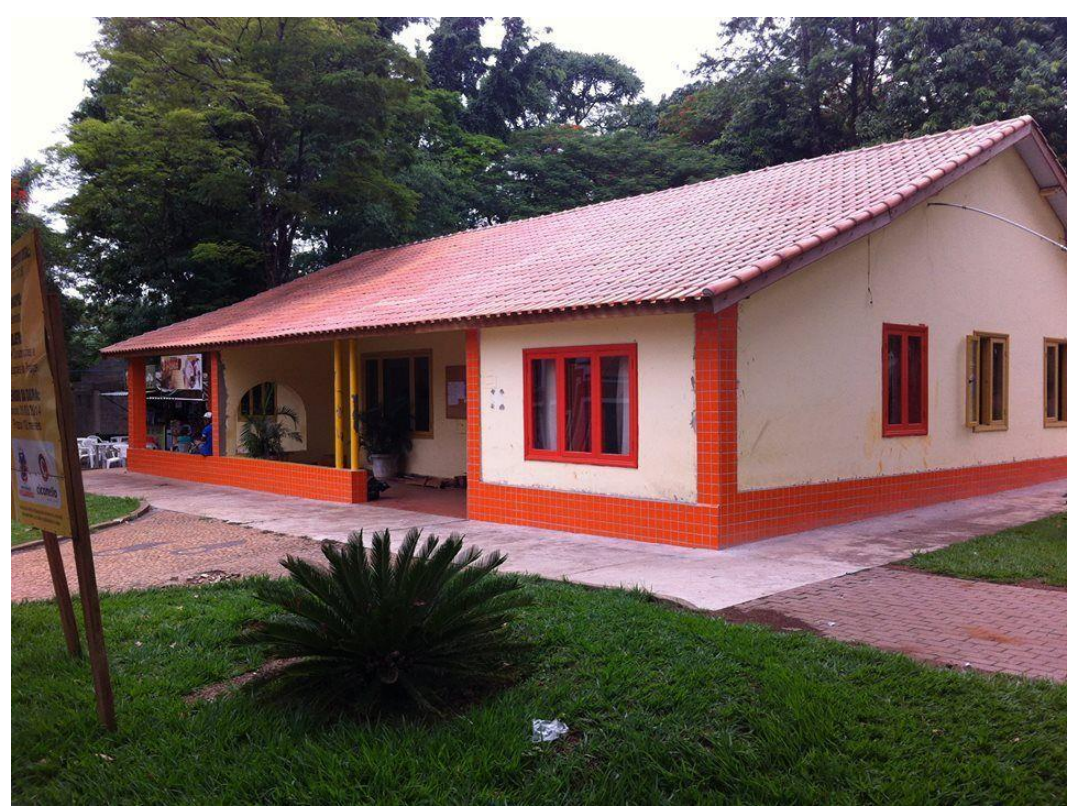

Figura 3: Casa de Charles Hogenboom, na Praça dos Pioneiros em Holambra durante reforma (2014). Fonte: Arquivo pessoal.

Figure 3: House of Charles Hogenboom, in the Square of the Pioneers in Holambra during reform (2014). Source: Personal file.

Este e outros exemplos apontam em direção à um desinteresse público e privado da sociedade holambrense em questões de patrimônios histórico ${ }^{9}$ e artístico. Apesar das construções em estado de deterioração e perda das características originais, em 2006, aprovaram-se na Câmara Municipal da Estância Turística de Holambra as Leis 563 e 564 (ambas de 10 de julho de 2006) que se referem à criação de um conselho e aos procedimentos a serem tomados objetivando a organização histórico-cultural do patrimônio de Holambra como a implantação do Conselho Municipal de Defesa do Patrimônio Histórico, Cultural e Ambiental. O conselho seria capaz de preservar o patrimônio municipal por meio do tombamento. A criação deste conselho não ocorreu até a atualidade. Como prova desta ineficácia político-administrativa tem-se como consequência atual, a descaracterização da casa de C. Hogenboom, como descrita no parágrafo anterior, e o abandono das outras construções listadas.

É possível que o patrimônio histórico de Holambra não se detenha somente aos edifícios físicos, mas também que hajam patrimônios imateriais. Estes nunca percebidos, hoje passam despercebidos e em fins de abandono para as gerações seguintes. Como um processo natural de hibridismo cultural e adaptação social, é comum que o uso da língua neerlandesa perca seu espaço entre os holandeses e descendentes e que, num futuro próximo, tais descendentes não sejam capazes de passar adiante aos seus filhos a língua holandesa, os costumes, hábitos e tradições de seus pais e avós.

Mas é preciso preservar as memórias de uma história, seja por meio dos edifícios, de fotografias, de objetos, e de contos. O que se observa na atual Estância Turística de Holambra é uma cenarização da paisagem urbana $^{10}$ que trata de representar o que está presente no imaginário social 
da sociedade brasileira sobre o que é holandês, ou seja, aplica-se no território, de forma visual, o conteúdo da cultura holandesa baseada no estereótipo. Este cenário, agrada aos turistas, "mantém" viva a relação entre os dois países e identifica a cidade como este "pedacinho da Holanda no Brasil".

É evidente, portanto, que o turismo em Holambra, baseado na cultural holandesa, tem interesse prioritariamente econômico uma vez que é deixado a que se desenvolva pelas mãos dos empresários locais que oferecem os serviços turísticos de hospedagem, alimentação e serviços de lazer inerentes a uma paisagem construída para aqueles turistas que buscam uma cidade agradável e tranquila e repleta de símbolos desta cultura do estereótipo.

\section{Considerações finais}

Viu-se que o município de Holambra, e mais propriamente dito, o espaço urbano, tem dado uma especial atenção ao aprimoramento visual e paisagístico do turismo a partir de questões que permeiam este tema na pós-modernidade. $\mathrm{O}$ apelo visual que remete à espetacularização da vida $\mathrm{e}$ do meio turístico são comprovações de um turismo que se desenvolve por meios econômicos voltados ao consumo de mercadorias, de paisagens, de modos de vida e regulações de status.

Não somente em Holambra, mas em cidades de interesse turístico que tem como principal atração sua construção e ornamentação urbana remetidos às "vilas europeias 11 ", como também em Gramado/RS, Campos do Jordão/SP e Monte Verde/MG, estas cidades estão construindo cenários reais repletos de símbolos e elementos imaginários que são facilmente e rapidamente identificados e consumidos pelos turistas. Neste jogo de espetacularizar a vida e consumir paisagens, não somente o turismo é valorizado, mas outros agentes econômicos presentes nestes territórios são passivos de beneficiarem-se da atratividade que estes destinos oferecem como o mercado imobiliário, o setor de serviços (turístico e não turístico), e a construção civil.

Diante deste cenário, questiona-se o papel do poder público nas ações voltadas ao desenvolvimento turístico, uma vez que estes territórios são frutos da vida social e apresentam uma história intrínseca e anterior à apropriação turística. A cultura neste meio, passa a ser consumida ao invés de apropriada. O valor dado ao consumo fugaz e superficial desta cultura europeia que se oferece aos forasteiros parece suficiente para movimentar a atividade turística e preencher os anseios e desejos daquele que se deslocam. Percebe-se que não há uma necessidade em aprofundar o interesse dos visitantes aos locais que visitam e propiciar a disponibilidade de acesso a instrumentos e meios culturais de real expressividade daqueles territórios. O usufruto turístico acontece em demonstrar em redes sociais e meios de comunicação em massa o momento vivido, diferentemente do conhecimento adquirido e da cultura apreendida. 
Na pós-modernidade, pode ser que os destinos turísticos e turistas, pelo menos nos casos mencionados, tenham encontrado os caminhos, nos quais, os interesses se convergem e o encontro de ambos seja suficientemente superficial e artificial. Além disso, as redes sociais e as publicações em meios massivos contribuem para promover ambos. Os turistas se inflamam ao terem o retorno social que necessitam para 0 preenchimento do próprio ego, e os destinos que se promovem cada vez mais nos diversos meios.

Diante desta discussão, considera-se que resgatar (e tornar acessível) o patrimônio cultural, histórico e artístico de destinos turísticos, não somente os mencionados, mas de outros; pode representar um avanço no aprofundamento do desfrute turístico tanto da localidade quanto do turista. Para a localidade, representa um aprofundamento cultural e social das bases que o sustentam como destino. Além disso, esta cultura intrínseca do território, antes mesmo de sua turistificação, estará disponível para as próximas gerações como um aprendizado de uma época com mais valores e dificuldades tecnológicas.

Acredita-se que tornar-se-ia também, um destino mais sustentável, pois tem como atrativo sua própria história, evitando assim que novos atrativos espetaculares e poluidores visualmente sejam construídos. Além disso, resgatar o patrimônio significa respeitar o passado, e usufruí-lo em prol da construção de um futuro com bases de valor. Outro ponto é a flexibilização do público turístico do destino, sendo que, valorizados os patrimônios locais, outros tipos de turistas podem surgir, aumento o fluxo, o tempo de visita e os gastos no local.

Para os turistas, a experiência a partir do patrimônio pode representar também um aprofundamento mais próximo do real na cultura que se busca, uma vez que as bases do conhecimento têm razão histórica e verídica. $O$ turista terá a oportunidade de descobrir um interesse em patrimônios históricos e, desta forma, mudar seu jeito de fazer turismo.

Finalmente, acredita-se que o resgate e a acessibilidade de patrimônios em destinos turísticos sejam capazes de promover a educação sócio responsável e criar oportunidades em educação patrimonial e sustentabilidade.

Holambra, no interior de São Paulo, vive o ápice de seu turismo, infelizmente este turismo tem apresentado um viés artificializado e voltado para a espetacularização de sua paisagem e mais do que isso, negado seu interesse em preservar sua história e seus patrimônios materiais e imateriais. A Holambra antiga, anterior à urbanização, detentora de história e autenticidade sofre com as ações características de governos municipais preocupados em somente embelezar, fantasiar sua paisagem turística. Quais ações poderiam reverter as iniciativas deste turismo predatório, e incentivar o resgate patrimonial de Holambra? Quais agentes do território podem ser responsáveis por tais ações? Quais órgãos de proteção ao patrimônio poderiam ser responsabilizados?

É preciso que este artigo seja visto como uma crítica construtiva principalmente para a Prefeitura Municipal da Estância Turística de 
Holambra e todos os outros responsáveis até a atualidade pelo descaso com o patrimônio holambrense. Vamos construir a Holambra que queremos? Qual Holambra queremos?

\section{Referências}

BAUMAN, Z. Vida líquida. tradução Calor Alberto Medeiros. Rio de Janeiro: Jorge Zahar Ed, 2007.

BESSA, A.S.M. A construção das paisagens turísticas nos descaminhos da Estrada Real. 2011. 280 p. Tese (Doutorado) - Faculdade de Arquitetura e Urbanismo de São Paulo, 2011.

BRASIL. MINISTÉRIO DO TURISMO. Secretaria Nacional de Políticas de Turismo, Departamento de Estruturação, Articulação e Ordenamento Turístico, Coordenação Geral de Segmentação. Turismo Cultural: orientações básicas. Brasília, 2008.

CARLOS, A.F.A. O turismo e a produção do não lugar. In: YÁZIGI, E.; CARLOS, A.F.A.; CRUZ, R.C.A. (Orgs). Turismo: espaço, paisagem e cultura. 3. ed. São Paulo: Hucitec, 2002. p. 133 - 155.

CARNEIRO, R.J.M. Organização da cidade: Planejamento municipal, plano diretor e urbanificação. - São Paulo: Maxlimonade, 1998.

CONSEIL DE L'EUROPE. Facettes du paysage Réflexions et propositions pour la mise en œuvre de la Convention européenne du paysage. Strasbourg Cedex, 2012. Disponível em : $<$ http://www.coe.int/t/dg4/cultureheritage/heritage/landscape/Publications/Fac ettes fr.pdf.> Acesso em: 13/11/2014.

CONSEIL DE L'EUROPE. Glossaire du système d'information du conseil de l'Europe de la convention européenne du paysage. L6. Disponível em:

$<$ http://www.coe.int/t/dg4/cultureheritage/heritage/landscape/GlossaryL6 fr.p df $>$ Acesso em: 13/11/2014.

DOMINGUES, A. A paisagem revisitada. Finisterra, XXXVI, n 72, p. 55-66, 2001. Disponível em: <http://www.ceg.ul.pt/finisterra/numeros/200172/72 05.pdf >. Acesso em: 15/09/2014.

DEBORD, G. A sociedade do espetáculo. tradução Estela dos Santos Abreu. Rio de Janeiro: Contraponto, 2013.

FINO, P.; QUEIROZ, O. Políticas públicas de turismo no Estado de São Paulo: evolução da legislação no caso das Estâncias. Anais do 5은 Congresso Latino-Americano de Investigação Turística. São Paulo, 2012. Disponível em: <http://gtci.com.br/congressos/congresso/2012/pdf/eixo2/Fino Queiroz.pdf>. Acesso em: 15/09/14

HAYLLAR, B. et al. Turismo em cidades: espaços urbanos, lugares turísticos. Rio de Janeiro: Elsevier, 2011.

ISNARD, H. O espaço geográfico. Livraria Almedina: Coimbra, 1982. 
LEITE, M.A.F.P. Destruição ou desconstrução?. São Paulo: Editora Hucitec, 1994.

LEMOS, A.I.G; GALVANI, E. (orgs.) Geografia, tradição e perspectivas: interdisciplinaridade, meio ambiente e representação. - 1ํ ed. - Buenos Aires CLACSO; São Paulo: Expressão Popular, 2009.

LUCHIARI, M.T.D.P. Turismo e Meio ambiente na Mitificação dos lugares. Turismo em Análise. São Paulo. II (1):35-43 maio 2000.

MONTE-MÓR, R.L. O que é o urbano no mundo contemporâneo. Revista Paranaense de Desenvolvimento, Curitiba, n.111, p.09-18, jul./dez. 2006.

MORANDI, S.; GIL, I.C. Espaço e turismo. São Paulo: Copidart Editora, 2001.

PELEGRINI, S.C.A. Cultura e natureza: os desafios das práticas preservacionistas na esfera do patrimônio cultural e ambiental. Revista Brasileira de História. São Paulo, v. 26, № 51, p. 115-140. 2006

PIRES, M.S. Turismo e pós-modernidade: teoria, cultura e sustentabilidade (Dissertação de Mestrado Profissional). Brasília: UNB, 2009.

SANTOS, M. Pensando o espaço do homem. São Paulo: Editora Hucitec, 1982.

SANTOS, M. Metamorfoses do espaço habitado: fundamentos teóricos e metodológicos da Geografia. $1^{\circ}$ ed. São Paulo: Hucitec, 1988.

SANTOS, M. Técnica, espaço e tempo. São Paulo: Hucitec, 1998.

SANTOS, M. Por uma Geografia Nova: Da crítica da Geografia a uma Geografia Física. - 6. Ed. - São Paulo: Editora da Universidade de São Paulo, 2004 - (Coleção Milton Santos; 2).

SANTOS, M. A natureza do espaço: Técnica e tempo, razão e emoção. 4. Ed 4, reimpr. - São Paulo: Editora da Universidade de São Paulo, 2008. (Coleção Milton Santos; 1).

SANTOS, M. Metamorfoses do Espaço habitado: Fundamentos Teóricos e Metodológicos da Geografia. - 6. Ed. 2. Reimp. - São Paulo: Editora da Universidade de São Paulo, 2014.

SILVA, M.G.L. Cidade turísticas: Identidades e cenários de lazer. São Paulo: Aleph, 2004.

SOUZA, M.J. Políticas públicas e o lugar do turismo. Brasília: Universidade de Brasília; Departamento de Geografia: Ministério do Meio Ambiente, 2002.

URRY, J. O olhar do Turista: lazer e viagens nas sociedades contemporâneas. Tradução Calor Eugênio Marcondes de Moura. - 3oe ed. São Paulo: Studio Nobel: SESC, 2001.

YÁZIGI, E. A alma do lugar: turismo, planejamento e cotidiano em litorais e montanhas. - 2 ed. - São Paulo: Contexto, 2001.

YÁZIGI, E. (Org.). Turismo e Paisagem. São Paulo: Contexto, 2002. 


\section{Websites consultados}

Câmara Municipal da Estância Turística de Holambra. Disponível em: http://www.camaraholambra.com.br/?z=noticias \&x=255. Acesso em: 19/05/2015.

Embrapa. Disponível em: http://www.holambra.cnpm.embrapa.br/hloca.html. Acesso em: 18/05/2015.

World Mapz. Disponível em: http://br.worldmapz.com/photo/93155 pt.htm. Acesso em: 22/05/2015.

\section{Notas:}

${ }^{1}$ O termo "estâncias" é a denominação oficial adotada no Brasil e que corresponde Europa, as "estações", naquele continente classificadas em termais ou hidrominerais, climáticas e balneárias" (PUPO, 1974 apud FINO, 2012, p. 2).

${ }^{2}$ Essas são características do segmento de Turismo Cultural: Compreende as atividades turísticas relacionadas à vivência do conjunto de elementos significativos do patrimônio histórico e cultural e dos eventos culturais, valorizando e promovendo os bens materiais e imateriais da cultura (MINISTÉRIO DO TURISMO, 2006, p.13)

${ }^{3}$ PIRES, Marina S. (2009) O turismo pós-moderno apresenta duas correntes, sendo uma primeira caracterizada por um turista que busca resgatar valores perdidos, valorizando locais que vanguardam características originais e autenticidade das manifestações culturais, e procura preencher as necessidades humanas de cultura e conhecimento. O outro turista pós-moderno é aquele que busca destino que remetem ao simulacro da vida, a espaço propriamente de lazer e diversão, com espaços que englobam reflexos na cultura da fantasia, criando mundos paralelos.

${ }^{4}$ BAUMAN, Zygmunt (2007). A liquidez vem do fato que os líquidos não têm uma forma, ou seja, são fluídos que se moldam conforme o recipiente nos quais estão contidos, diferentemente dos sólidos que são rígidos e precisam sofrer uma tensão de forças para moldar-se a novas formas. Desta forma, Bauman apresenta a modernidade líquida como que se traduz em laços sociais frágeis e inconstantes, o que provoca insegurança e medo. Nada é sólido ou conserva a forma por muito tempo.

${ }^{5}$ DEBORD, Guy (2013). O espetáculo é a aparência que confere integridade e sentido a uma sociedade esfacelada e dividida. É a forma mais elaborada de uma sociedade que desenvolveu ao extremo o 'fetichismo da mercadoria' (felicidade identifica-se a consumo).

6 CARLOS, Ana F. A. (2002). Diferencia-se do lugar pelo seu processo de constituição, é nesse caso produto da indústria turística que com sua atividade produz simulacros ou constrói simulacros de lugares, através da não-identidade.

7 "Espaço urbano é esse 'tecido' que nasce nas cidades e se estende para além delas, sobre o campo e as regiões, uma síntese da antiga dicotomia cidade campo, um terceiro elemento na oposição dialética cidade-campo, uma manifestação material e socioespacial da sociedade urbana-industrial contemporânea estendida, virtualmente, por todo espaço social” (MONTEMÓR, 2006, p. 190).

${ }^{8}$ SILVA, Maria da G. L. (2004) "Os cenários do lazer surgem a partir da apropriação de imagens com o objetivo de comport repertórios de lugares turísticos que possam ser facilmente identificáveis ou categorizados pelo turista. Um dos aspectos mais 
importantes dessa 'cenarização' em localidades turísticas é uma espécie de 'arquitetura de fachada'... (p. 22).

9 "Há que se admitir que embora a definição de patrimônio cultural busque contemplar as mais diversas formas de expressão dos bens da humanidade, tradicionalmente o referido conceito continua sendo apresentado de maneira fragmentada, associado às distintas áreas do conhecimento científico que o definem como patrimônio cultural, natural, paisagístico, arqueológico e assim por diante. Contudo, nos últimos anos do século $X X$ e início do século $X X I$, já se depreende que essas áreas se inter-relacionam e que, independentemente das suas respectivas categorias, todo o patrimônio se configura e se engendra mediante suas relações com a cultura e o meio. Sem dúvida, hoje se reconhece que a cultura é construída historicamente, de forma dinâmica e ininterrupta, alterando-se e ampliando seu cabedal de geração em geração, a partir do contato com saberes ou grupos distintos" (PELEGRINI, 2006: 117).

10 ... "observa-se que predominantemente os poderes públicos e a iniciativa privada no Brasil têm investido em programas superficiais que criam simulacros de preservação ou cenários vazios de historicidade, cujo intuito é buscar o desenvolvimento do turismo, não raro de um turismo indiscriminado e prejudicial, muitas vezes dissociado das prerrogativas do turismo cultural. (129) ... fenômeno definido pelos geógrafos como gentrificação, ou seja, a população residente foi expulsa do local e o espaço arquitetônico sofreu uma "restauração" aparente". (PELEGRINI, 2006: 130).

11 SILVA, Maria da G. L. da. (2004). "O cenário denominado genericamente 'europeu' que estas cidades apresentam, na verdade é uma reprodução de um tipo específico da paisagem europeia, encontrada em algumas regiões da Europa Central, em países como a Alemanha, França e Suiça (...) (p. 65).

João Luiz van Ham Mello: Universidade Federal de Minas Gerais, Belo Horizonte, MG, Brasil.

E-mail: joaovanham@hotmail.com

Link para o currículo Lattes: http://lattes.cnpq.br/7308373790631708

Solano de Souza Braga: Universidade do Estado de Minas Gerais, Belo Horizonte, MG, Brasil.

E-mail: solanobraga@yahoo.com.br

Link para o currículo Lattes: http://lattes.cnpq.br/3774316982731542

Data de submissão: 14 de outubro de 2016

Data de recebimento de correções: 7 de fevereiro de 2017

Data do aceite: 7 de fevereiro de 2017

Avaliado anonimamente 